\title{
The influence of local officials' promotion incentives on carbon emission in Yangtze River Delta, China
}

Article

Accepted Version

Creative Commons: Attribution-Noncommercial-No Derivative Works 4.0

Meng, H., Huang, X., Yang, H., Chen, Z., Yang, J., Zhou, Y. and $\mathrm{Li}, \mathrm{J}$. (2019) The influence of local officials' promotion incentives on carbon emission in Yangtze River Delta, China. Journal of Cleaner Production, 213. pp. 1337-1345. ISSN 0959-6526 doi: https://doi.org/10.1016/j.jclepro.2018.12.036 Available at https://centaur.reading.ac.uk/81861/

It is advisable to refer to the publisher's version if you intend to cite from the work. See Guidance on citing.

Published version at: https://www.sciencedirect.com/science/article/pii/S0959652618337387

To link to this article DOI: http://dx.doi.org/10.1016/j.jclepro.2018.12.036

Publisher: Elsevier

All outputs in CentAUR are protected by Intellectual Property Rights law, including copyright law. Copyright and IPR is retained by the creators or other copyright holders. Terms and conditions for use of this material are defined in the End User Agreement.

www.reading.ac.uk/centaur 
Central Archive at the University of Reading

Reading's research outputs online 


\section{The influence of local officials' promotion incentives on carbon emission in Yangtze River Delta, China}

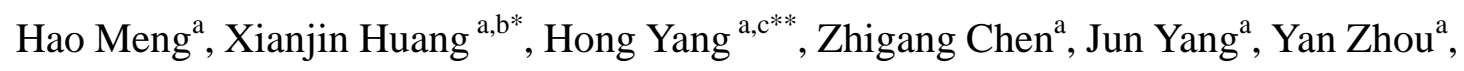
Jianbao $\mathrm{Li}^{\mathrm{a}}$

${ }^{a}$ School of Geography and Ocean Science, Nanjing University, Nanjing 210023, China

${ }^{\mathrm{b}}$ The Key Laboratory of the Coastal Zone Exploitation and Protection, Ministry of Land and Resources, Nanjing 210023, China

${ }^{\mathrm{c}}$ Department of Geography and Environmental Science, University of Reading, Reading RG6 $6 \mathrm{AB}, \mathrm{UK}$

* Corresponding author.

E-mail addresses: menghao09@163.com (H. Meng), hxj369@nju.edu.cn (X. Huang), hongyanghy@gmail.com (H. Yang), zgchen@nju.edu.cn (Z.Chen), jycug_edu@163.com (J. Yang), zhy555ylp@163.com (Y. Zhou), lijianbao888@126.com (J. Li).

Addresses: School of Geography and Oceanography Sciences, Nanjing University, 163 Xianlin Street, Nanjing, Jiangsu, China.

\section{Highlights:}

- A theoretical framework was constructed to analyse the influence of promotion incentives on carbon emissions.

- Local officials' promotion sources, tenure and age significantly influenced total carbon emission.

- Local officials with a professional background in economics and management has a significant influence on carbon reduction. 
Abstract: China's carbon emissions is heavily influenced by economic growth, which can be largely related to the local officials' promotion incentives. The current study was conducted to test the hypothesis that the influence of local officials' individual characteristics on carbon emissions was driven by the promotion incentives. Yangtze River Delta where carbon emissions accounted for around 13.95\% of China's total emissions was selected as the research area. The multiple linear regression model was applied to determine the relationship between local officials' characteristics and total carbon emissions and carbon emissions from different sectors. The results indicated that local officials' promotion source, tenure and age significantly influenced the total carbon emission. Despite insignificance influence of officials' academic level on carbon emissions, the professional background in economics and management had a significant influence on carbon reduction. Our results indicated the importance of local officials' promotion incentives for carbon emission in China. Therefore, low carbon development should be included as an important part of official promotion system.

Keywords: Carbon Emissions; Local Officials; Promotion Incentives; Yangtze River Delta; China

\section{Graphical abstract :}

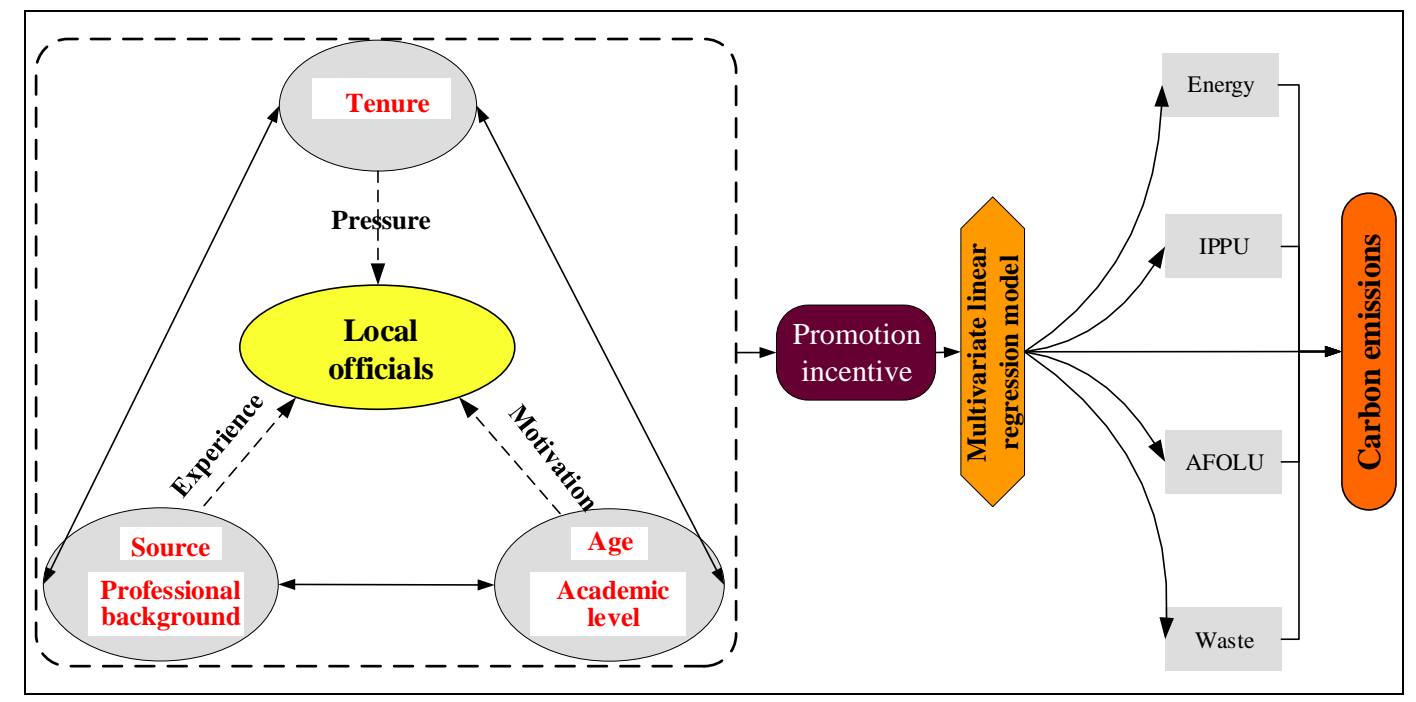




\section{Introduction}

Human activities have accelerated the increase in greenhouse gases (GHGs) in atmosphere, which exacerbate global warming (Anagnostou et al., 2016; Friedlingstein et al., 2014; MacDougall and Friedlingstein, 2015). In 2016, $\mathrm{CO}_{2}$ concentration reached at $403.3 \pm 0.1 \mathrm{ppm}, \mathrm{CH}_{4}$ reached at $1853 \pm 2 \mathrm{ppb}$ and $\mathrm{N}_{2} \mathrm{O}$ reached at $328.9 \pm 0.1$ ppb, increasing by 45\%, 157\% and 22\% than pre-industrial level (before 1750) (Yang et al., 2013). Particularly, China surpassed the US and became global largest $\mathrm{CO}_{2}$ emitter in 2005 (Janssens-Maenhout et al., 2017). With sustained economic growth and rapid urbanization and industrialization, China's total carbon emissions may continue to increase in the next years. In the Paris climate conference, China announced that the country will achieve the peak of $\mathrm{CO}_{2}$ emission by around 2030, with best efforts to peak early (Liu et al., 2014). On June 1, 2017, the US declared its withdrawal from the Paris Agreement, which will very likely impact carbon emission from the US. Nevertheless, China still plan to launch the national carbon emissions trading market. Therefore, China's action on carbon emission receives increasing global attention (Gibney, 2016).

In spite of many studies, the driving mechanism of China's carbon emission is still not well known. The driving factors include appearance factors and fundamental factors(Geist and Lambin, 2002). In general, appearance factors include economy, population, energy and technology (Ang and Su, 2016; Ye et al., 2017). The traditional theories, such as the environmental Kuznets down "U" curve, carbon emissions decoupling, pollution shelter and other theories, come from the economic point of view to explain the mechanism of carbon emissions. The fundamental factors, including laws and regulations, national and government policies, land use, and human behaviour (Lai et al., 2016), are more responsive to an in-depth explanation of the driving mechanisms.

According to North's theory of institutional change (Besley et al., 2012), material and human capital growth and technological progress are only the result of economic growth, rather than the inherent source of growth, and are the root determinants of institutional arrangements. In west governments, the political reputation model explains the impact of political incentives on regional development. To seek re-election, politicians revise policies on taxation, environment and education according to voters' preferences (Ales et al., 2014). Different from their counterparts, Chinese local officials are more likely to be held to "higher authorities' appointment" rather than voter election. The most influential theories of China's economic growth miracle are "Federalism, Chinese Style" (Jin et al., 2005) and "Promotion Tournament Model Theory" (Pu and $\mathrm{Fu}, 2018$ ), which states that the incentives of local officials are an important engine of China's economic development. Many studies have found that the main reason for China's increasing $\mathrm{CO}_{2}$ emission is the extensive economic growth (Liu and Diamond, 2005; Zhang et al., 2013). And therefore there may be some relationships between the incentives of official promotion and carbon emission in China. Understanding the influence of local officials on carbon emissions is very important for global climate action, especially for China, the largest $\mathrm{CO}_{2}$ emitter. However, previous researches largely overlooked the role of government officials in carbon emission. 
Officials are different actors. They act also according to their own political demands to make the appropriate promotion response. The most extreme example is the recent change of the American president and the following climate policy to further support fossil energy. To the best of our knowledge, there is no available study on the influence of local official on carbon emissions in China. To meet the knowledge gap, the relationship between carbon emissions and characteristics of local officials motivated by the promotion incentives were analysed. Totally 25 cities in the Yangtze River Delta (YRD), one of the areas with most rapid increase in carbon emissions in China (Li et al., 2017), were researched during the period of 2000-2010. The results reveal the underlying drivers of carbon emission and provide a new perspective of China's carbon reduction.

\section{Material and methods}

Based on a theoretical framework, multiple linear regression models were constructed to calculate the relationship between local officials' characteristics and carbon emissions, including total carbon emission and carbon emissions from the four sectors including Energy, IPPU (industrial processes and product use), AFOLU (agriculture, forestry and other land use), and Waste.

\subsection{Multiple linear regression model}

\subsubsection{Variable selection}

In China, the carbon emissions are mainly driven by GDP, GDP per capita (PGDP), population (POP), fixed asset investments (INV) and industrial structure (second industry accounted for GDP, IS) (Peters et al., 2017). Therefore, the above factors were selected as control variables.

Constitution of the Communist Party of China requires the contingent of cadres has four principles including "revolutionization", "young", "knowledge" and "specialization". It also stipulates that each tenure of local official is five years and officials must retire at the age of 60 years old (Burns and Wang, 2010). Due to the measure difficulty of "revolutionary", age, tenure and education have become more important factors in local officials' promotion. Educational background of local officials can be measured by both profession and academic level (Dreher et al., 2009). The promotion source was the key variable influencing local officials' promotion experience (Chen et al., 2017; Dreher et al., 2009). As the saying goes, "a new broom sweeps clean". Compared with officials promoted from their home cities, those transferred from other cities usually developed strategies to showcase their unique ideas and highlight their future performance. However, due to the lack of sufficient awareness of the local information, the new policies may not be in line with local situation, and the environmental costs brought about by these policies can be very high (Duan and $\mathrm{Hu}$, 2014). Therefore, promotion source was chosen to represent the promotion experience of local officials.

Multicollinearity verification was conducted for all variables using the Variance Inflation Factor (VIF) in Stata13.0. The maximum VIF is 9.46, less than 10. Due to the significant collinearity between GDP with other variables, GDP was excluded, but 
PGDP, POP, INV and IS were included as the control variables (Krebs et al., 2012).

Based on the above analysis, a theoretical framework was constructed to analyse the influence of local officials' promotion incentives on carbon emission in three ways: promotion experience, pressure during current tenure and motivation for future promotion.
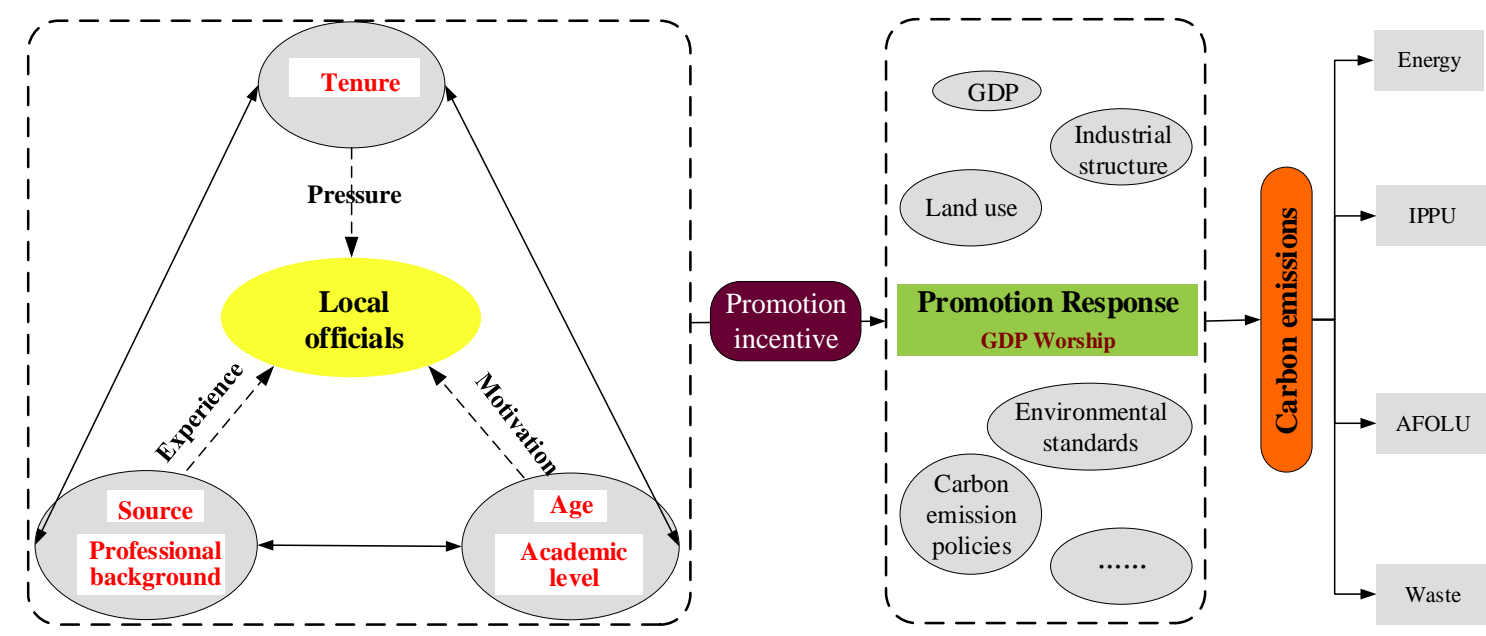

Fig. 1. The analytical framework of local official's promotion incentives and carbon emissions.

Notes: GDP represents gross domestic product; IPPU represents carbon emission from industrial processes and product use sector; and AFOLU represents carbon emissions from agriculture, forestry and other land use sector.

\subsubsection{Model establishment}

The panel data of 25 cities in the YRD from 2000 to 2010 were applied to examine the specific impact of the promotion of local officials on the carbon emissions by estimating the following econometric model (Sun et al., 2017):

$$
E_{i t}^{r}=C+\alpha_{j} X_{i t}^{j}+\beta_{k} L_{i t}^{k}+\mu_{i t}
$$

where $E_{i t}^{r}$ represents the carbon emissions in city $i$ during the period $t$, the total carbon emissions and carbon emissions from Energy, IPPU, AFOLU, and Waste. $C$ represents a constant term, and $X_{i t}^{j}$ represents control variables. $L_{i t}^{k}$ represents local officials' individual characteristics; $\mu_{i t}$ denotes the error term; and $\alpha_{j}$ and $\beta_{k}$ are the regression coefficients of variable groups $X_{i t}^{j}$ and $L_{i t}^{k}$. According to the previous theoretical framework, the above model was developed by selecting five aspects to measure the heterogeneity of local officials including the mayor and the municipal party secretary using Equations (2) and (3):

$$
\begin{aligned}
& E_{i t}^{r}=C+\alpha_{1} P G D P_{i t}+\alpha_{2} P O P_{i t}+\alpha_{3} I_{N V_{i t}}+\alpha_{4} I S_{i t}+\beta_{1} \text { Msource }_{i t}+\beta_{2} \text { Mpro_economic }_{i t} \\
& \quad+\beta_{3} \text { Mtenure }_{i t}+\beta_{4} \text { Mage }_{i t}+\beta_{5} \text { Macademic_level }_{i t}+\mu_{i t} \\
& E_{i t}^{r^{\prime}}=C+\alpha_{1} \text { PGDP }_{i t}+\alpha_{2} \text { POP }_{i t}+\alpha_{3} I_{N V_{i t}}+\alpha_{4} I S_{i t}+\beta_{6} \text { Psource }_{i t}+\beta_{7} \text { Ppro_economic }_{i t} \\
& \quad+\beta_{3} \text { Ptenure }_{i t}+\beta_{4} \text { Page }_{i t}+\beta_{5} \text { Pacademic_level }_{i t}+\mu_{i t}
\end{aligned}
$$


where source $_{i t}$ is the promotion sources of city $i$ in period $t(0=$ promote from local city, 1 = promote from another city). pro_economic $i t$ denotes that the local officials of $i$ in period $t$ have a professional background in economics and management $(0=$ no economic and management professional background, $1=$ have such professional background). tenure $e_{i t}$ denotes the current tenure of the local officials in city $i$ in period $t$. age $e_{i t}$ denotes the age of local officials of city $i$ in period $t$ (unit: year). aca_level $_{i t}$ denotes the academic level of local officials $(1=$ Associate degree, $2=$ Bachelor degree, 3 = Master degree and 4 = Doctoral degree).

Based on all data from 25 cities during the period of 2000-2010, software STATA Version 13 (Stata Corp, College Station, Texas, USA) was used to conduct the above models. Panel data generally had a difference between the fixed effect (FE) model, random effect (RE) model or ordinary least square (OLS) model (Xu et al., 2015). An F test with Clustering Robust Standard Errors suggested that the FE-model was better than the OLS-model. The further analysis using the Hausman test indicated $\mathrm{p}$ value greater than 0.05 (Yang et al., 2017), so the RE-model was considered as the most effective model.

\subsection{Research area and data source}

The YRD is located in the eastern coast of mainland China, including Shanghai direct-controlled municipality, Jiangsu Province and Zhejiang Province and 25 prefecture-level cities (Fig. 2). The YRD accounted for $2.19 \%$ of China's land area, $11.59 \%$ of China's population and 20.02\% of China's GDP in 2015 (National Bureau Statistics of China, 2016). The YRD has developed into one of China's economic centres, as well as the world's sixth largest urban agglomeration (Li et al., 2018).

However, the YRD consumed $13.69 \%$ of China's energy and emited $13.95 \%$ of China's s total carbon emissions in 2015, equivalent to Japan's carbon emissions (Janssens-Maenhout et al., 2017). Environmental pollution has been a big challenge in the region, especially with frequent hazes. In 2015, the annual days with safe air quality decreased to less than 250 days. YRD has been a microcosm of whole China's carbon emission and air pollution. The research in YRD will be helpful to understand carbon emission in other regions in China, and it may also provide experience for cities in other countries. 


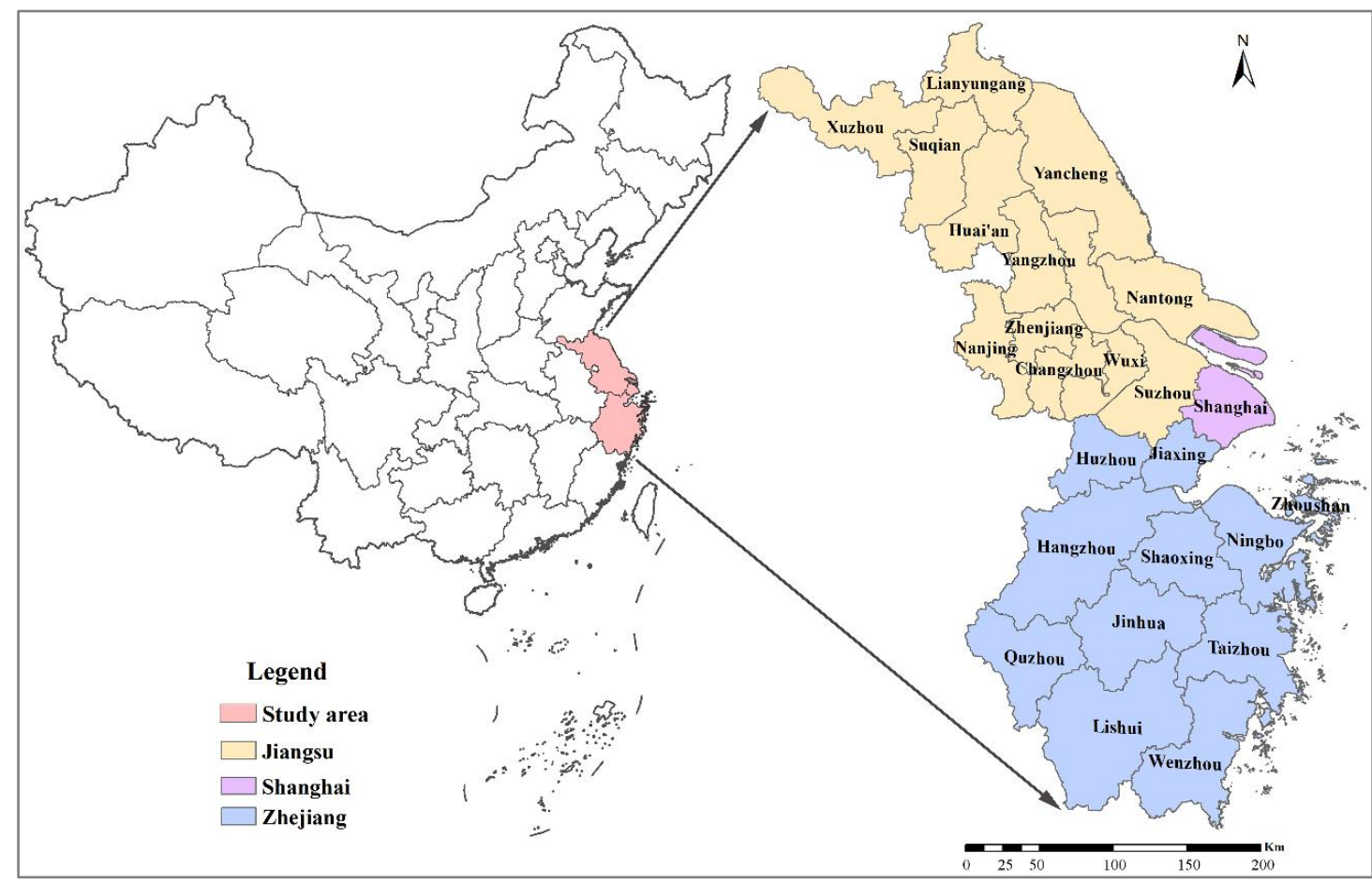

Fig. 2. Research area in the Yangtze River Delta, China

Local officials' individual characteristics were obtained from several databases. The tenure and name of the mayor and municipal party committee of the city were obtained from Zecheng Net (http://www.hotelaah.com/liren/index.html). Based on the name of the official, all local official's yearly resumes were searched in Baidu (www.baidu.com), and the resumes include the promotion source, professional background, tenure, age and academic level. It is worth noting that some local officials were not appointed at the same time. If the appointment date was before June, officials' tenure was counted from that year. Otherwise, it was calculated from next year. GDP per capita (PGDP), population (POP) and investment in fixed assets and secondary industry values (INV) were obtained from the annual Shanghai Statistical Yearbook, Jiangsu Statistical Yearbook and Zhejiang Statistical Yearbook for the period of 2001-2011.

High-precision spatial grid $\left(0.1^{\circ} \times 0.1^{\circ}\right)$ carbon emissions data obtained from the Emission Database for Global Atmospheric Research (EDGAR), a widely used database for carbon emissions and air pollution research (Janssens-Maenhout et al., 2017; Peters et al., 2017), were used to calculate the carbon emissions from 25 cities in the YRD. Table 1 shows the descriptive statistics of the variables. It is noteworthy that the education levels of some local officials are missing, and the panel data are unbalanced. 
Data description.

\begin{tabular}{|c|c|c|c|c|c|c|c|}
\hline & Variable & Unit & Observations & Mean & $\begin{array}{c}\text { Std. } \\
\text { deviation }\end{array}$ & Minimum & Maximum \\
\hline \multirow{5}{*}{$\mathrm{EC}$} & Total & $\operatorname{TgC}$ & 275 & 8.56 & 9.87 & 0.01 & 62.77 \\
\hline & Energy & $\mathrm{TgC}$ & 275 & 6.31 & 8.08 & 0.01 & 51.3 \\
\hline & IPPU & $\mathrm{TgC}$ & 275 & 1.11 & 1.36 & 0 & 9.53 \\
\hline & AFOLU & $\operatorname{TgC}$ & 275 & 0.74 & 0.83 & 0 & 4.66 \\
\hline & Waste & $\operatorname{TgC}$ & 275 & 0.38 & 0.34 & 0 & 1.42 \\
\hline PGDP & & $\begin{array}{l}10^{6} \\
\text { CHY/person }\end{array}$ & 275 & 277.58 & 188.76 & 39.71 & 952.28 \\
\hline POP & & $10^{6}$ person & 275 & 5.18 & 2.71 & 1.05 & 15.31 \\
\hline INV & & $10^{9} \mathrm{CHY}$ & 275 & 84.20 & 85.37 & 4.22 & 463.05 \\
\hline IS & & $\%$ & 275 & 51.83 & 6.36 & 29.6 & 66.6 \\
\hline \multirow{2}{*}{ Source } & Msource & I & 275 & 0.73 & 0.45 & 0 & 1 \\
\hline & Psource & I & 275 & 0.48 & 0.5 & 0 & 1 \\
\hline Professional & Mpro_economic & l & 263 & 0.59 & 0.49 & 0 & 1 \\
\hline background & Ppro_economic & I & 263 & 0.46 & 0.5 & 0 & 1 \\
\hline \multirow{2}{*}{ Tenure } & Mtenure & year & 275 & 2.82 & 1.81 & 1 & 9 \\
\hline & Ptenure & year & 275 & 3.16 & 1.93 & 1 & 10 \\
\hline \multirow{2}{*}{ Age } & Mage & year & 275 & 49.58 & 4.65 & 39 & 70 \\
\hline & Page & year & 275 & 51.85 & 4.51 & 43 & 73 \\
\hline Academic & Maca_level & I & 269 & 1.84 & 0.77 & 0 & 3 \\
\hline level & Paca_level & 1 & 265 & 1.82 & 0.67 & 0 & 3 \\
\hline
\end{tabular}

Notes: EC refers to carbon emission. PGDP refers to GDP per capita. POP refers population. INV refers to fixed asset investment. IS refers to industrial structure. M refers to the mayor. P refers to the municipal party committee.

\subsection{Calculation of carbon emissions}

EDGAR provides data that contain not only the total $\mathrm{CO}_{2}, \mathrm{CH}_{4}$ and $\mathrm{NO}_{2}$ but also emissions data for different sectors. However, the sectors were classified in accordance with the IPCC1996 code. According to "2006 IPCC Guidelines for National Greenhouse Gas Inventories", sectors were reclassified to Energy, IPPU, AFOLU, and Waste using ArcGIS 10.2 (ESRI Inc, Redlands, California, USA) (Table 2). 
Table 2

Carbon emissions from difference sectors.

\begin{tabular}{|c|c|c|c|}
\hline Categories & $\mathrm{CO}_{2}$ & $\mathrm{CH}_{4}$ & $\mathrm{~N}_{2} \mathrm{O}$ \\
\hline \multirow{13}{*}{ Energy } & Energy industry; & $\begin{array}{l}\text { Energy manufacturing } \\
\text { transformation; }\end{array}$ & $\begin{array}{l}\text { Energy manufacturing } \\
\text { transformation; }\end{array}$ \\
\hline & $\begin{array}{l}\text { Transformation } \\
\text { non-energy use; }\end{array}$ & Non-road transportation; & Non-road transportation; \\
\hline & $\begin{array}{l}\text { Combustion in } \\
\text { manufacturing industry; }\end{array}$ & Road transportation; & Road transportation; \\
\hline & $\begin{array}{l}\text { International and domestic } \\
\text { aviation; }\end{array}$ & Energy for buildings; & Energy for buildings; \\
\hline & Road transportation; & Fugitive from solid; & Oil production and refineries; \\
\hline & Non-road ground & Oil production and & \\
\hline & transport; & refineries; & \\
\hline & International and domestic & Gas production and & \\
\hline & shipping; & distribution; & \\
\hline & Energy for buildings; & & \\
\hline & Fugitive from solid; & & \\
\hline & Oil production and & & \\
\hline & refineries; & & \\
\hline \multirow{5}{*}{ IPPU } & Non-metallic mineral & Industrial process and & Industrial process and product \\
\hline & processes; & product use; & use; \\
\hline & Chemical processes & & \\
\hline & solvents; & & \\
\hline & Metal processes; & & \\
\hline \multirow{4}{*}{ AFOLU } & Agricultural soils; & Enteric fermentation; & Manure management; \\
\hline & $\begin{array}{l}\text { Large Scale Biomass } \\
\text { Burning; }\end{array}$ & Manure management; & Agricultural soils; \\
\hline & & Agricultural soils; & $\begin{array}{l}\text { Indirect } \mathrm{N}_{2} \mathrm{O} \text { emissions from } \\
\text { agriculture; }\end{array}$ \\
\hline & & Agricultural waste burning; & Agricultural waste burning; \\
\hline \multirow{3}{*}{ Waste } & Solid waste disposal; & Solid waste disposal; & Waste solid and wastewater; \\
\hline & Fossil Fuel Fires; & Waste water; & Fossil Fuel Fires; \\
\hline & & Fossil Fuel Fires; & $\begin{array}{l}\text { Indirect emissions from } \mathrm{NO}_{\mathrm{x}} \\
\text { and } \mathrm{NH}_{3} \text {. }\end{array}$ \\
\hline
\end{tabular}

Notes: IPPU refers to industrial processes and product use sector. AFOLU refers to agriculture, forestry and other land use sector.

Regarding the greenhouse gases, the warming effects of $\mathrm{CO}_{2}, \mathrm{CH}_{4}$ and $\mathrm{N}_{2} \mathrm{O}$ were $76 \%, 16 \%$ and $6.2 \%$, respectively (Pachauri et al., 2014). To estimate the total warming effect, different greenhouse gases were converted to $\mathrm{CO}_{2}$-equivalent emissions and then converted into the amount of carbon emissions as follows: 


$$
E_{\text {carbon }}=\left(E_{\mathrm{CO}_{2}}+G W P_{\mathrm{CH}_{4}} * E_{\mathrm{CH}_{4}}+G W P_{\mathrm{N}_{2} \mathrm{O}} * E_{\mathrm{N}_{2} \mathrm{O}}\right) * M_{\mathrm{r}_{\mathrm{C}}} / M_{\mathrm{rOO}_{2}}
$$

where the Global Warming Potential $(G W P)$ represents the warming capacity of greenhouse gases relative to the carbon dioxide $\left(\mathrm{CO}_{2}\right) . G W P_{\mathrm{CH}_{4}}$ and $G W P_{\mathrm{N}_{2} \mathrm{O}}$ adopt the 100-year GWP $\left(\mathrm{GWP}_{100}\right)$ standard value in "the Climate change 2014: synthesis report", which are 28 and 265, respectively (Pachauri et al., 2014). $E_{\text {carbon }}, E_{\mathrm{CO}_{2}}$, $E_{\mathrm{CH}_{4}}$ and $E_{\mathrm{N}_{2} \mathrm{O}}$ represent the emissions of carbon, $\mathrm{CO}_{2}, \mathrm{CH}_{4}$ and $\mathrm{N}_{2} \mathrm{O}$, respectively. $M_{r_{C}}$ and $M_{r_{C_{2}}}$ are the relative molecular mass of $\mathrm{C}$ and $\mathrm{CO}_{2}, M_{r_{C}}=12$, and $M_{r_{C}}$ $=44$

\section{Results}

\subsection{Spatiotemporal pattern of carbon emission}

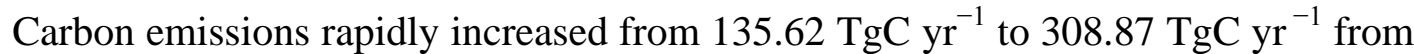
2000 to 2010, with an average annual growth rate of $7.77 \%$ (Fig. 3). The growth rate showed an inverted U-shaped curve, from $2.32 \%$ in 2001 to $15.25 \%$ in 2004, and then fell to $5.25 \%$ in 2010. From the emission structure, in 2010, the YRD exhausted 502.31 $\mathrm{TgCO}_{2}$ eq $\mathrm{yr}^{-1} \cdot \mathrm{CO}_{2}$ accounted for $90.4 \% . \mathrm{CH}_{4}$ and $\mathrm{N}_{2} \mathrm{O}$ contributed only $7.3 \%$ and $2.3 \%$, respectively. In terms of the emission sectors, the Energy sector accounted for the highest proportion of carbon emissions, from $68.78 \%$ in 2000 to $75.69 \%$ in 2010. IPPU sector contributed $12.35 \%-13.96 \%$ of total carbon emissions between 2000 and 2010, with average growth rate of $8.98 \%$. AFOLU and Waste contributed $6.87 \%$ and $3.48 \%$ of total carbon emissions, respectively; and the average annual growth rates were $1.97 \%$ and $2.20 \%$, respectively.

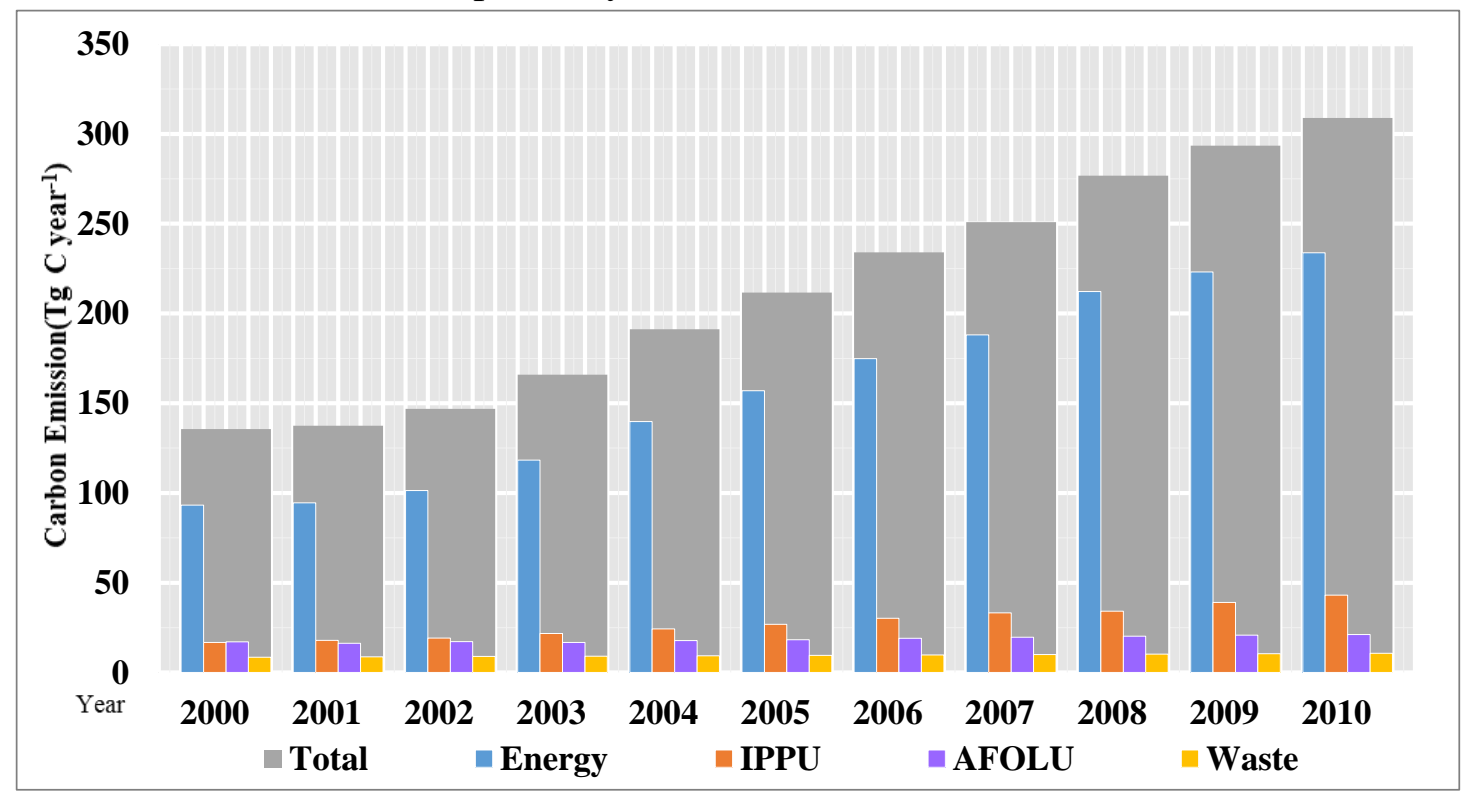

Fig. 3 Carbon emissions in Yangtze River Delta from 2000 to 2010

The total carbon emissions in the YRD experienced a rapid growth process but with markedly spatial differences (Fig. 4). In 2000, Shanghai had the largest carbon emissions, followed by Xuzhou and Yancheng, while Zhoushan had the smallest one. In 2005, the carbon emissions from Shanghai, Taizhou, Suzhou, Ningbo, Wenzhou and 
other cities increased markedly. In 2010, the total carbon emissions in all cities further increased. The higher carbon emissions were concentrated mainly in Shanghai City, North Jiangsu Province and the coastal area in Zhejiang Province, while the lower carbon emissions appeared mainly in the southwest of Zhejiang Province. The highest value of $62.77 \mathrm{TgC}$ in Shanghai was more than 2380 times greater than the lowest value of $0.03 \mathrm{TgC}$ in Zhoushan.

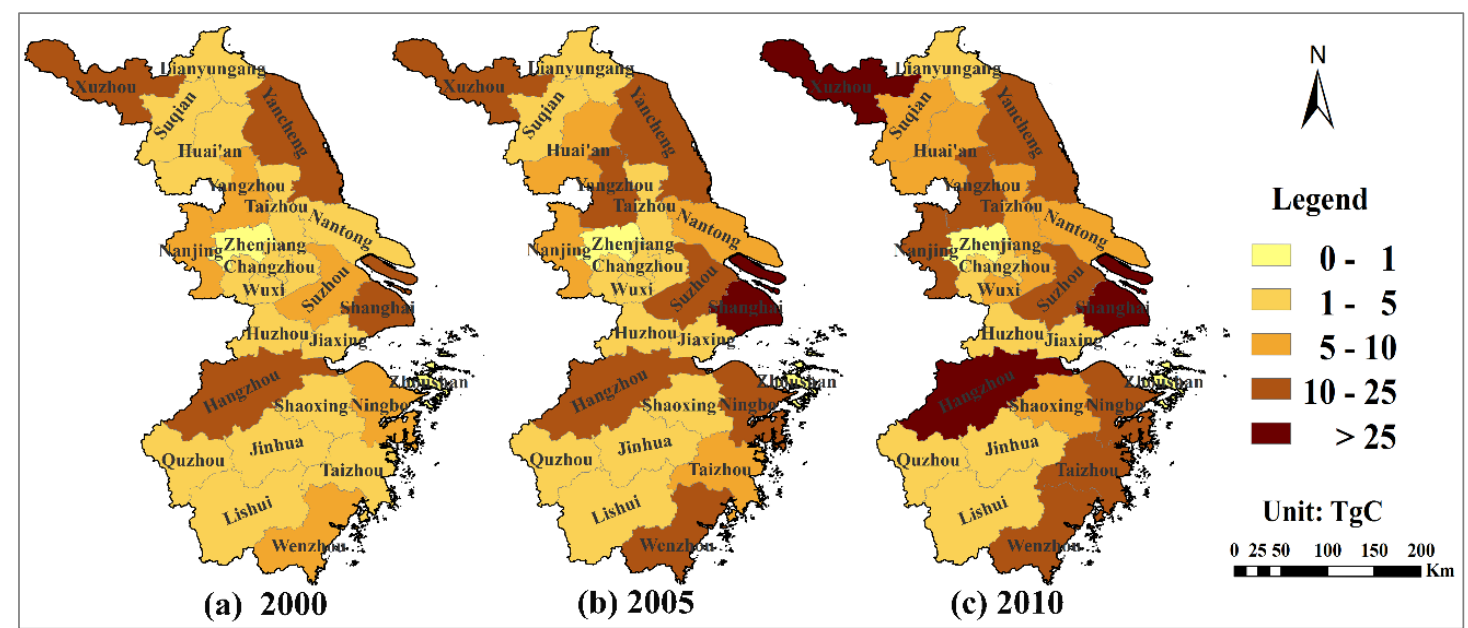

Fig. 4 Spatial pattern of carbon emissions in the Yangtze River Delta from 2000 to 2010

\subsection{Total carbon emissions}

Models (1) and (2) indicated that the coefficients of the control variables (INV, POP and IS) played prominent roles in carbon emissions. The effects of INV and IS were significantly positive at the $1 \%$ level, suggesting that economic, fixed asset investments and secondary production significantly affect carbon emissions. The estimated coefficient of the variable POP is also positive, but not as significant as the other variables, and significant at the 5\% level, indicating that the impact of the population on carbon emissions may be limited. However, PGDP is significantly negative at the $1 \%$ level, indicating that PGDP growth can reduce carbon emissions. According to the theory of Environmental Kuznets Curve (EKC), the carbon emissions in the YRD region exceeded the critical point of the EKC; with the further increase in income per capita, carbon emissions will gradually decrease (Jalil and Mahmud, 2009; Stern and Common, 2001).

There are some significant correlations between carbon emissions and local officials' promotion experience, pressure during current tenure and motivation of future promotion (Table 3).

\subsubsection{Local officials' promotion experience}

Local officials' promotion experience was mainly reflected in the promotion source and professional background. From the promotion source of local officials (Table 2), the average of Msource was 0.73 , and the average of Psource was 0.48 , indicating that $73 \%$ mayors and $48 \%$ municipal party secretaries were promoted from other cities. The estimated coefficients for Msource and Psource were both significantly positive at the levels of 5\%, respectively. Therefore, the promotion source of local officials had 
a certain impact on carbon emission. The mayors and municipal party secretaries who were transferred from other cities were more likely to cause an increase in carbon emissions than locally promoted officials.

The estimated coefficients of Mpro_economic and Ppro_economic were negative, but only Ppro_economic passed the $10 \%$ significance level test, indicating that municipal party secretaries with a professional background in economics or management were conducive to carbon reduction.

\subsubsection{Local officials' promotion pressure}

Fig. 5 shows that the YRD's local officials had a shorter tenure. The average tenure of mayors and municipal party secretaries were 3 years and 4 years, respectively, much shorter than the statutory five-year tenure. This phenomenon was more obvious for the mayors than the municipal party secretaries. The regression coefficients of Ptenure was significant at the $1 \%$ level, and the mayors' tenure had insignificant effect on local carbon emissions. As the tenure increased, the influence of the municipal party secretaries on carbon emissions was in accordance with the inverted U-shaped curve. The inflection point of the curve was approximately 4.3 years.
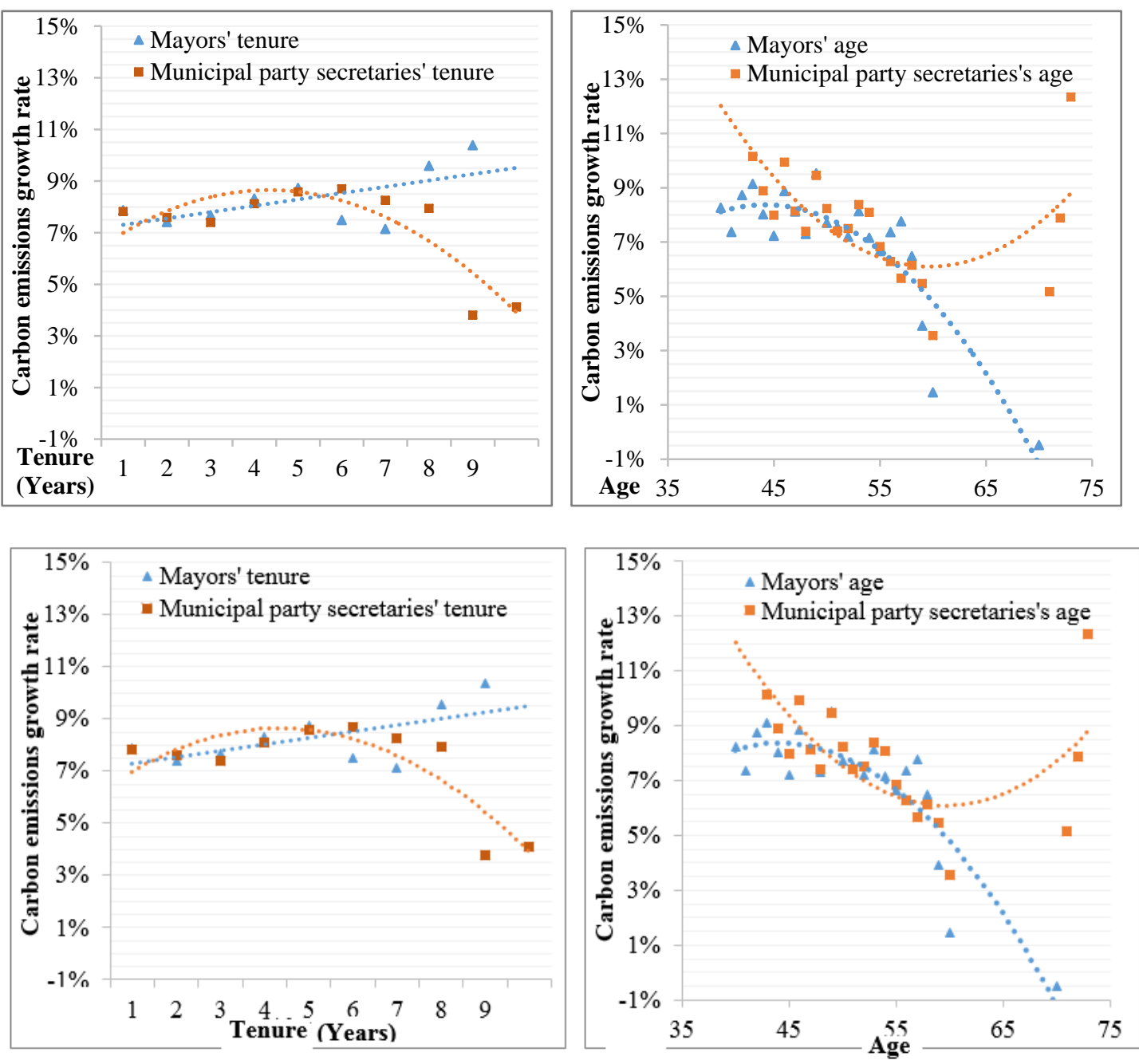

Fig. 5 Carbon emission growth rates on different local officials' tenures and ages 


\subsubsection{Local officials' promotion motivation}

Local officials' age had a positive effect on the total carbon emissions, but only the mayors' age was statistically significant (Table 3). Furthermore, there was a non-linear relationship between the age of local officials and the growth rate of carbon emissions (Fig. 5). The mayors' age and carbon emissions showed an inverted U-shaped curve, while the municipal party secretaries' age and carbon emissions showed a U-shaped curve. The marginal effect of the mayors on carbon emissions shows a change from positive to negative as the age increases. However, the effect of age of the municipal party secretaries on carbon emissions was insignificant.

Local officials had a higher academic level. Around $95.51 \%$ of the mayors and municipal party secretaries had bachelor degree or above, and $14.00 \%$ of local officials had doctoral degrees. The overall proportion of mayors with a master or doctorate degree was higher than the proportion of the municipal party secretaries. The estimated coefficient of Paca_level was positive and significant, while the Maca_level was positive but insignificant.

\subsection{Carbon emissions from different sectors}

To further explore the effect of officials' promotion on carbon emissions, the total carbon emissions were decomposed into four sectors including Energy, IPPU, AFOLU and Waste and a random effect model was conducted (Table 3). Local officials' promotion sources, professional background, academic level, tenure and age had significant effects on carbon emissions from different sectors. The effects of local officials' individual characteristics on total carbon emissions and carbon emissions from different sectors were relatively consistent.

The tests of goodness of fit of the four sectors were different (Table 3). Energy sector had the best fit, with $\mathrm{R}^{2}$ values of 0.8466 and 0.8612 , respectively; and the AFOLU sector had the minimum, with $\mathrm{R}^{2}$ of 0.5349 and 0.6045 . This indicates that the promotion of local officials had a larger impact on carbon emissions from Energy sector, but limited impact on the carbon emissions from AFOLU sector. However, the results of the model estimates in each sector were similar as the total carbon emissions. 
Table 3

The influence of local officials' individual characteristics on carbon emission

\begin{tabular}{|c|c|c|c|c|c|c|c|c|c|c|}
\hline \multirow{2}{*}{ Model } & \multicolumn{2}{|c|}{ EC } & \multicolumn{2}{|c|}{ Energy } & \multicolumn{2}{|c|}{ IPPU } & \multicolumn{2}{|c|}{ AFOLU } & \multicolumn{2}{|c|}{ Waste } \\
\hline & (1) & (2) & (3) & (4) & (5) & (6) & (7) & (8) & (9) & (10) \\
\hline PGDP & $-7.74 \mathrm{e}-07 * * *$ & $-2.97 \mathrm{e}-05 * * *$ & $-1.08 \mathrm{e}-05^{* * *}$ & $-1.38 \mathrm{e}-05^{* * *}$ & $-2.57 \mathrm{e}-06^{* * * *}$ & $-7.49 \mathrm{e}-06^{* *}$ & $-5.35 \mathrm{e}-06^{* * *}$ & $-5.52 \mathrm{e}-06 * * *$ & $-7.04 \mathrm{e}-07 * * *$ & $-8.29 \mathrm{e}-07 * * *$ \\
\hline POP & $0.0234 * *$ & $0.0281 * *$ & $0.0198 * * *$ & $0.0230 * *$ & $0.00310 * * *$ & $0.00303 * * *$ & $0.0004899^{*}$ & 0.000408 & $0.00112 * * *$ & $0.00113 * * *$ \\
\hline INV & $0.00536^{* * *}$ & $0.00560 * * *$ & $0.00433 * * *$ & $0.00448 * * *$ & $0.000775 * * *$ & $0.000854 * * *$ & $0.000185 * * *$ & $0.000199 * * *$ & $4.30 \mathrm{e}-05^{* * *}$ & $4.49 \mathrm{e}-05^{* * *}$ \\
\hline IS & $0.131 * *$ & $0.151 * * *$ & $0.106 * *$ & $0.126 * * *$ & $0.0253 * * *$ & $0.0293 * * *$ & $0.00948 * * *$ & $0.00721 * * *$ & $0.00119 * * *$ & 0.000407 \\
\hline Msource & $0.222 * *$ & & $0.176^{*}$ & & $0.0142 *$ & & -0.00073 & & -0.00161 & \\
\hline Mpro_economic & -0.157 & & 0.0234 & & 0.0696 & & 0.0187 & & -0.000913 & \\
\hline Mtenure & $0.00413 * *$ & & -0.00224 & & $0.00984 *$ & & $0.00359 *$ & & $0.000347 *$ & \\
\hline Mage & $0.168 * * *$ & & $0.157 * * *$ & & $0.0193 * *$ & & $0.00497 * * *$ & & $0.000701^{*}$ & \\
\hline Maca_level & 0.236 & & 0.187 & & 0.0105 & & 0.00979 & & $0.00443 *$ & \\
\hline Psource & & $0.865 * *$ & & $0.808 * *$ & & $0.118 * *$ & & $-0.0529 * * *$ & & $0.00911 * * *$ \\
\hline Ppro_economic & & $-0.00588^{*}$ & & 0.0271 & & $-0.0379^{*}$ & & $0.0234 * *$ & & $-0.00512 *$ \\
\hline Ptenure & & $-0.313 * * *$ & & $-0.267 * * *$ & & $-0.0530 * * *$ & & $-0.00481 *$ & & $-0.000304 *$ \\
\hline Page & & -0.208 & & $-0.160 * * *$ & & $-0.0410 * * *$ & & $-0.00463 * *$ & & $-0.00191 * * *$ \\
\hline Paca_level & & $0.688 * * *$ & & $0.507 *$ & & $0.134 * * *$ & & $0.0241 * * *$ & & $0.0145 * * *$ \\
\hline Constant & $6.342 *$ & $-13.55 * * *$ & $4.946 * *$ & $-11.24 * * *$ & $1.097 * * *$ & $-1.689 * * *$ & $-0.292 * *$ & $-0.138 * * *$ & $-0.315^{* * *}$ & $-0.358 * * *$ \\
\hline $\mathrm{R}^{2}$ & 0.8572 & 0.8407 & 0.8466 & 0.8612 & 0.8238 & 0.8034 & 0.5349 & 0.6045 & 0.8095 & 0.8396 \\
\hline
\end{tabular}

Notes: ***, **, and * indicate significances at levels of 1\%, 5\%, and 10\%, respectively. 1, 3, 5, 7, and 9 were conducted using Equation $2.2,4,6,8$, and 10 were conducted using Equation

3. 


\subsection{Robustness test}

Because model outputs depend on model setting and indicator construction, robustness tests were performed to verify the stability and reliability of the results. The robustness was examined by adjusting model's core variables and samples.

(1) Change variables. The square term of tenure (tenure ${ }^{2}$ ) and age $\left(\right.$ age $^{2}$ ) were included, and the robustness was evaluated. The results show that the coefficients of the variables such as source, pro_economic, tenure, age, and aca_level in Table 4 were mostly consistent with those in Table 3 , indicating the robustness of the previous results.

(2) Change samples. There are 138 mayors and party committee secretaries in the current research, among which 16 people, such as Chen Liangyu, Mao Xiaoping, and Ji Jianye, were withdrawn due to job-related crime or malfeasance. Same as the adjustment of variables, such mayors and municipal party committee secretaries were excluded and a robustness test was conducted. The results were still robust.

Table 4

Results of robustness tests

\begin{tabular}{|c|c|c|c|c|}
\hline \multirow{2}{*}{ Model } & \multicolumn{2}{|c|}{$\mathrm{EC}$} & \multicolumn{2}{|c|}{$\mathrm{EC}$} \\
\hline & (11) & (12) & (13) & (14) \\
\hline PGDP & $-7.74 \mathrm{e}-06 * * *$ & $-2.97 \mathrm{e}-05 * * *$ & $-7.74 \mathrm{e}-07 * * *$ & $-3.59 \mathrm{e}-05^{* * *}$ \\
\hline POP & $0.0235^{* * *}$ & $0.0282 * * *$ & $0.0234 * * *$ & $0.0272 * * *$ \\
\hline INV & $0.00530 * * *$ & $0.00554 * * *$ & $0.00536 * * *$ & $0.00574 * * *$ \\
\hline IS & $0.133 * *$ & $0.134 * * *$ & $0.131 * *$ & $0.152 * * *$ \\
\hline Msource & $0.0324 * *$ & & 0.222 & \\
\hline Mpro_economic & -0.0975 & & 0.157 & \\
\hline Mtenure & $0.00413 * *$ & & -0.00413 & \\
\hline Mage & $1.604 * * *$ & & $-0.168 * * *$ & \\
\hline Maca_level & 0.263 & & 0.236 & \\
\hline Psource & & $0.819 * *$ & & -0.142 \\
\hline Ppro_economic & & $-0.0339 *$ & & -0.117 \\
\hline Ptenure & & $-0.338 * * *$ & & $-0.461 * * *$ \\
\hline Page & & -1.172 & & $0.218 * * *$ \\
\hline Paca_level & & $0.728 * * *$ & & $0.768 * *$ \\
\hline Mtenure $^{2}$ & -0.102 & & & \\
\hline Ptenure $^{2}$ & & $0.0573 * * *$ & & \\
\hline Mage $^{2}$ & $-0.0143 * * *$ & & & \\
\hline Page $^{2}$ & & $0.0193 *$ & & \\
\hline Constant & $-37.48^{*}$ & $20.85 * *$ & 6.342 & $-13.07 * * *$ \\
\hline $\mathrm{R}^{2}$ & 0.6867 & 0.7079 & 0.8381 & 0.8572 \\
\hline
\end{tabular}

Notes: $* * * * *$, and $*$ indicate significances at the levels of $1 \%, 5 \%$, and $10 \%$, respectively. 11 and 13 were conducted using Equation 2. 12 and 14 were conducted using Equation 3.

\section{Discussion}

In this study, a theoretical framework was developed to explore the influence of local 
officials with different characteristics on carbon emissions under the incentives of promotion in 25 cities in the YRD. The results indicate that local officials were not conducive to local carbon reductions under promotion incentives. In addition, local officials' promotion experience, pressure and motivation had different effects on changes in carbon emissions.

\subsection{The significant effect of local officials' promotion incentives on carbon emissions}

Since the Reform and Opening policy in late 1970s, there is a phenomenon of "GDP worship" in Chinese officials (He et al., 2018). Local officials equalled reducing carbon emissions to slowing GDP growth at least in their administration period, and therefore local officials paid little attention to reduce carbon emissions (Smith, 2013). Promotion incentives influence the local officials' performance on carbon reduction, but the influence on mayors and municipal party secretaries are more complicated and probably less affected by the economic performance (Zhu, 2011). In addition, the marked economic differences between cities reduce the comparability.

Local officials neither feel pressure to act on carbon emissions from the central government nor do they have to deal with international pressures (Ye et al., 2008). Under the promotion incentives, local officials tend to develop industries with fast GDP growth and often with high energy consumption, such as cement, steel, aluminium, chemicals, and energy industries (Cai et al., 2016; Heede, 2014). In the AFOLU sector, although local officials had great enthusiasm for building land expansion, the carbon emissions from land use change are also influenced by natural factors, such as climate, soil and vegetation type (Lai et al., 2016; Liu et al., 2014). Therefore, the model's fitting effect was relatively poor $\left(\mathrm{R}^{2}=0.5349\right.$ and 0.6045$)$. China has established regulations of waste management, the enforcement of regulation by local officials are not very successful (Yang, 2014; Yang et al., 2016). Due to the scarcity of political resources and economic resources, local officials often relaxed the standards of environmental regulation, increasing carbon emissions in the waste sector, and creasing "pollution haven" in some areas (Yang et al., 2018) (Fig. 1).

\subsection{Effects of local officials' individual characteristics on carbon emissions}

Local official's individual characteristics can affect the government's development policies, which in turn will influence carbon emissions from the area (Dreher et al., 2009). Moreover, because the present study was conducted in one of China's most rapidly growing areas, the YRD, the effects can be much larger.

First, compared to officials transferred from other cities, locally promoted mayors and municipal party secretaries had better performance in terms of carbon reductions. Locally promoted officials who are familiar with the area situation will have the advantage to keep economic growth with relative less carbon emissions (Chen et al., 2017). Comparatively, officials who were transferred from other cities have relative less knowledge of local environment. They usually choose a new policy to replace the old policy to show their performance (Yang et al., 2016). In addition, they have to take a longer time to get the balance of economic development and environmental 
protection, with the possibility of increasing carbon emissions.

Second, local officials' tenure had a more complex impact on carbon emission. The carbon emissions during municipal party secretaries' tenure increased first and then decreased, an inverted U-shaped curve. A limited tenure for local officials will very possibly push them to take short-term policies and ignore the potential negative environmental impacts (Besley and Case, 1995). To show their "performance" and "ability", new officials have to quickly carry out a variety of projects to stimulate economic development, with the result of often unavoidably high carbon emissions. With the extension of tenure, officials obtain more clear information about their promotion, and the incentives effect on officials may decline gradually. At the same time, the officials' enthusiasm of developing economy reduced slowly. When the promotion of local officials become gradually stable (Julio and Yook, 2012), supervision also increases. With less sacrificing environment in exchange for economic development, the increase in carbon emissions will reverse. However, before leaving, officials may take into account the lagging effect of a low-carbon development. And their attitude towards carbon reduction can once again become negative, with a result of rebounded carbon emissions.

Third, the age of 60 has been set up as the retire age for city mayors in China. Therefore, the younger local officials, the higher expectations of promotion (Bu et al., 2016). To catch more promotion opportunities, young officials may prefer economic development to environmental protection, with the consequence of increasing carbon emissions ( $\mathrm{He}$ et al., 2018; $\mathrm{Pu}$ and $\mathrm{Fu}, 2018$ ). Our results indicate that after this turning point of 46.57 years old, the promotion incentives reduced markedly.

Finally, local officials' education is mainly reflected in the academic level and professional background. First, there is no significant relationship between local officials' academic levels and carbon emissions. This is in stark contrast to the results of South India where officials with higher education level can improve the allocation of regional resources, with a lower carbon emissions (Besley et al., 2012). Academic requirement is important for cadre selection and appointment in China, so local officials are keen to obtain high academic levels. Most local officials in the YRD have a Master's degree. Considering already heavy workload, there is wide concern how the local officials have sufficient time to complete the required courses for their part-time academic education. In China, higher education levels do not always equal to stronger awareness and more knowledge of environmental protection. Second, local officials who have a professional background in economic or management, are conducive to carbon reduction. From the turnover of Chinese leaders, it can be seen that Chinese officials' professional backgrounds gradually change from expert technical type to public management type (Yang et al., 2013). Previous officials are representatives of technical experts, and they pay more attention to the construction of big infrastructure projects, for example highway and coal-power plant. Although this helped the Chinese economy to take off, it came with a rapid increase in carbon emissions. Officials with professional background in economics or management are 
familiar with the laws of the macroeconomic operation, and can pay more attention to the long-term sustainable development in the area (Qi et al., 2008; Zheng et al., 2014).

\subsection{Policy implications of local officials' governance and carbon reduction}

To reduce carbon emissions, more attention should be paid to the fundamental factors causing the increase in carbon emissions. Local officials' promotion incentives should be improved at the institutional level. Our results provide suggestions for official selection and promotion in practice. First, more officials should be appointed from local cities. Second, the tenure of local officials can be, to some extent, extended. Third, less attention should be paid to the academic level above bachelor degree, but more attention should be given to the academic background.

"GDP worship" cannot sustain economic development and environmental protection, for example carbon reduction. In the evaluation of local officials, the proportion of GDP should be further reduced, but the proportion of environmental protection, particularly carbon reduction, should be increased. A multi-objective evaluation system including economic development and environmental protection should be adopted. In addition, low-carbon development should be prioritized.

\subsection{Limitation and future research}

Same as many studies, there are some limitations in the current study. EDGAR provided the carbon emissions grid data up to 2010, so it is unavailable for the analyses after 2011. In particular, the Chinese government has paid more attention to environmental protection after 2012 (Yang et al., 2015), and the effect of local officials' performance on carbon emissions may change. In addition, only the promotion source, education, tenure and age were selected to reflect the heterogeneity of local officials, and these characteristics may be imperfect to reflect the differences between all local officials. Local officials' gender, as well as the careers of military, state-owned enterprises, universities, and others can also affect their promotion (Dreher et al., 2009; Ericson, 2009). More research on these areas will improve our understanding of local official promote and carbon emissions in China.

\section{Conclusions}

From the three aspects of promotion experience, pressure during current tenure and motivation for future promotion, a theoretical framework was constructed to explore the influence of local officials' promotion incentives on China's carbon emissions in 25 cities in the Yangtze River Delta. The results indicated that:

(1) Locally promoted mayors and municipal party secretaries had better performance of reducing carbon emissions, compared to officials transferred from other cities.

(2) With the increase in tenure, the effect of local officials on carbon emissions had an inverted U-shaped relationship.

(3) Younger local officials were more likely to lead to increase in carbon emissions.

(4) The increase in the local officials' academic levels did not promote a reduction in carbon emissions. However, local officials with economic or managerial professional backgrounds were more conducive to carbon reduction. 
Therefore, encouraging promotion from their home cities, extending the tenure of local officials, and paying more attention to academic background rather than academic level can be helpful for China's carbon reduction.

\section{Acknowledgement}

This work was supported by the Clean Development Mechanism (CDM) projects of China (No. 1214073 and No. 2012065), the National Natural Science Foundation of China (No. 41571162, No. 41601592 and 41671171).

\section{References}

Ales, L., Maziero, P., Yared, P., 2014. A theory of political and economic cycles. Journal of Economic Theory 153, 224-251.

Anagnostou, E., John, E.H., Edgar, K.M., Foster, G.L., Ridgwell, A., Inglis, G.N., Pancost, R.D., Lunt, D.J., Pearson, P.N., 2016. Changing atmospheric $\mathrm{CO}_{2}$ concentration was the primary driver of early Cenozoic climate. Nature 533(7603), 380-384.

Ang, B., Su, B., 2016. Carbon emission intensity in electricity production: A global analysis. Energy Policy 94, 56-63.

Besley, T., Case, A., 1995. Does electoral accountability affect economic policy choices? Evidence from gubernatorial term limits. The Quarterly Journal of Economics 110(3), 769-798.

Besley, T., Pande, R., Rao, V., 2012. Just Rewards? Local Politics and Public Resource Allocation in South India. World Bank Economic Review 26(2), 191-216.

Bu, D., Zhang, C., Lin, T., 2016. Will political promotion expectation decrease the pay gap in state-owned enterprises in China? China Journal of Accounting Studies 4(1), 53-78.

Burns, J.P., Wang, X., 2010. Civil service reform in China: Impacts on civil servants' behaviour. The China Quarterly 201, 58-78.

Cai, B., Wang, J., He, J., Geng, Y., 2016. Evaluating $\mathrm{CO}_{2}$ emission performance in China's cement industry: an enterprise perspective. Applied energy 166, 191-200.

Chen, Z., Tang, J., Wan, J., Chen, Y., 2017. Promotion incentives for local officials and the expansion of urban construction land in China: Using the Yangtze River Delta as a case study. Land Use Policy 63, 214-225.

Dreher, A., Lamla, M.J., Lein, S.M., Somogyi, F., 2009. The impact of political leaders' profession and education on reforms. Journal of Comparative Economics 37(1), 169-193.

Duan, H., Hu, Q., 2014. Local officials' concerns of climate change issues in China: a case from Jiangsu. Journal of cleaner production 64, 545-551.

Ericson, R.E., 2009. Eurasian natural gas pipelines: the political economy of network interdependence. Eurasian Geography and Economics 50(1), 28-57.

Friedlingstein, P., Andrew, R.M., Rogelj, J., Peters, G.P., Canadell, J.G., Knutti, R., Luderer, G., Raupach, M.R., Schaeffer, M., van Vuuren, D.P., Le Quere, C., 2014. Persistent growth of CO2 emissions and implications for reaching climate targets. Nature Geoscience 7(10), 709-715.

Geist, H.J., Lambin, E.F., 2002. Proximate causes and underlying driving forces of tropical deforestation: Tropical forests are disappearing as the result of many pressures, both local and regional, acting in various combinations in different geographical locations. BioScience 52(2), 143-150.

Gibney, E., 2016. 2017 sneak peek: What the new year holds for science. Nature 541(7635), 14.

He, C., Mao, X., Zhu, X., 2018. Industrial dynamics and environmental performance in urban China. 
Journal of Cleaner Production 195, 1512-1522.

Heede, R., 2014. Tracing anthropogenic carbon dioxide and methane emissions to fossil fuel and cement producers, 1854-2010. Climatic Change 122(1), 229-241.

Jalil, A., Mahmud, S.F., 2009. Environment Kuznets curve for $\mathrm{CO}_{2}$ emissions: a cointegration analysis for China. Energy Policy 37(12), 5167-5172.

Janssens-Maenhout, G., Crippa, M., Guizzardi, D., Muntean, M., Schaaf, E., Dentener, F., Bergamaschi, P., Pagliari, V., Olivier, J., Peters, J., 2017. EDGAR v4. 3.2 Global Atlas of the three major Greenhouse Gas Emissions for the period 1970-2012. Earth Syst. Sci. Data Discuss.

Jin, H.H., Qian, Y.Y., Weingast, B.R., 2005. Regional decentralization and fiscal incentives: Federalism, Chinese style. Journal of Public Economics 89(9-10), 1719-1742.

Julio, B., Yook, Y., 2012. Political Uncertainty and Corporate Investment Cycles. Journal of Finance 67(1), 45-83.

Krebs, P., Koutsias, N., Conedera, M., 2012. Modelling the eco-cultural niche of giant chestnut trees: new insights into land use history in southern Switzerland through distribution analysis of a living heritage. Journal of Historical Geography 38(4), 372-386.

Lai, L., Huang, X., Yang, H., Chuai, X., Zhang, M., Zhong, T., Chen, Z., Chen, Y., Wang, X., Thompson, J.R., 2016. Carbon emissions from land-use change and management in China between 1990 and 2010. Science advances 2(11), 8.

Li, J., Huang, X., Kwan, M., Yang, H., Chuai, X., 2018. The effect of urbanization on carbon dioxide emissions efficiency in the Yangtze River Delta, China. Journal of Cleaner Production 188, 38-48.

Li, J., Huang, X., Yang, H., Chuai, X., Wu, C., 2017. Convergence of carbon intensity in the Yangtze River Delta, China. Habitat International 60, 58-68.

Liu, J.G., Diamond, J., 2005. China's environment in a globalizing world. Nature 435(7046), 1179-1186.

Liu, Y., Huang, X., Yang, H., Zhong, T., 2014. Environmental effects of land-use/cover change caused by urbanization and policies in Southwest China Karst area-A case study of Guiyang. Habitat International 44, 339-348.

MacDougall, A.H., Friedlingstein, P., 2015. The origin and limits of the near proportionality between climate warming and cumulative $\mathrm{CO}_{2}$ emissions. Journal of Climate 28(10), 4217-4230.

National Bureau Statistics of China, 2016. China statistical Yearbook 2014. China Statistics Press, Beijing.

Pachauri, R.K., Allen, M.R., Barros, V.R., Broome, J., Cramer, W., Christ, R., Church, J.A., Clarke, L., Dahe, Q., Dasgupta, P., 2014. Climate change 2014: synthesis report. Contribution of Working Groups I, II and III to the fifth assessment report of the Intergovernmental Panel on Climate Change. IPCC.

Peters, G.P., Le Quéré, C., Andrew, R.M., Canadell, J.G., Friedlingstein, P., Ilyina, T., Jackson, R.B., Joos, F., Korsbakken, J.I., McKinley, G.A., Sitch, S., Tans, P., 2017. Towards real-time verification of $\mathrm{CO}_{2}$ emissions. Nature Climate Change 7(12), 848-850.

Pu, Z., Fu, J., 2018. Economic growth, environmental sustainability and China mayors' promotion. Journal of Cleaner Production 172, 454-465.

Qi, Y., Ma, L., Zhang, H., Li, H., 2008. Translating a global issue into local priority: China's local government response to climate change. The Journal of Environment \& Development 17(4), 379-400.

Smith, G., 2013. Measurement, promotions and patterns of behavior in Chinese local government. 
Journal of Peasant Studies 40(6), 1027-1050.

Stern, D.I., Common, M.S., 2001. Is there an environmental Kuznets curve for sulfur? Journal of Environmental Economics and Management 41(2), 162-178.

Sun, C.W., Zhang, F., Xu, M.L., 2017. Investigation of pollution haven hypothesis for China: An ARDL approach with breakpoint unit root tests. Journal of Cleaner Production 161, 153-164.

Xu, G.L., Huang, X.J., Zhong, T.Y., Chen, Y., Wu, C.Y., Jin, Y.Z., 2015. Assessment on the effect of city arable land protection under the implementation of China's National General Land Use Plan (2006-2020). Habitat International 49, 466-473.

Yang, H., 2014. China must continue the momentum of green law. Nature 509(7502), 535.

Yang, H., Flower, R.J., Thompson, J.R., 2013. China's new leaders offer great hope. Nature 493, 163-163.

Yang, H., Huang, X., Thompson, J.R., Bright, R.M., Astrup, R., 2016. The crushing weight of urban waste. Science 351(6274), 674-674.

Yang, H., Huang, X., Thompson, J.R., Flower, R.J., 2015. Enforcement key to China's environment. Science 347(6224), 834-835.

Yang, H., Ma, M.G., Thompson, J.R., Flower, R.J., 2018. Waste management, informal recycling, environmental pollution and public health. Journal of Epidemiology and Community Health 72(3), 237-243.

Yang, Q., Geng, Y., Dong, H.J., Zhang, J.Q., Yu, X.M., Sun, L., Lu, X.R., Chen, Y.H., 2017. Effect of environmental regulations on China's graphite export. Journal of Cleaner Production 161, 327-334.

Ye, B., Jiang, J., Li, C., Miao, L., Tang, J., 2017. Quantification and driving force analysis of provincial-level carbon emissions in China. Applied Energy 198, 223-238.

Ye, Q., Li, M., Huanbo, Z., Huimin, L., 2008. Translating a global issue into local priority: China's local government response to climate change. Journal of Environment \& Development A Review of International Policy 17(4), 379-400.

Zhang, X.H., Wu, L.Q., Zhang, R., Deng, S.H., Zhang, Y.Z., Wu, J., Li, Y.W., Lin, L.L., Li, L., Wang, Y.J., Wang, L.L., 2013. Evaluating the relationships among economic growth, energy consumption, air emissions and air environmental protection investment in China. Renewable \& Sustainable Energy Reviews 18, 259-270.

Zheng, S., Kahn, M.E., Sun, W., Luo, D., 2014. Incentives for China's urban mayors to mitigate pollution externalities: The role of the central government and public environmentalism. Regional Science and Urban Economics 47, 61-71.

Zhu, Y., 2011. "Performance legitimacy" and China's political adaptation strategy. Journal of Chinese Political Science 16(2), 123-140. 